\title{
Varieties of English Accents: A Study of the Degree of Preference and Intelligibility Among Second- Year English Major Students at Maejo University
}

\author{
Daranee Choomthong (ดาราณี ชุมทอง) \\ Assistant Professor, Faculty of Liberal Arts, Maejo University, \\ Chiang Mai, Thailand \\ daranee.choomthong@gmail.com \\ Supaporn Manowong (สุภาพร มโนวงศ์) \\ Assistant Professor, Faculty of Liberal Arts, Maejo University, \\ Chiang Mai, Thailand \\ supapornmı@gmail.com
}

\begin{abstract}
Thailand is regarded as a country of the expanding circle (EC). The fact that English has become a working language in the ASEAN community makes it vital that Thai students are aware of the varieties of English. The study examined the perception of English majors towards varieties of English pronunciation. Listening tasks spoken by speakers in the expanding circle (EC), the inner circle (IC) and outer circle (OC), were presented to students enrolled in a course on Sound and English Sound System. The students rated accent preference and intelligibility. A semi-structure interview was included for more in-depth information. The results revealed that the variety of English that was perceived as the most favorable accent by the participants was English spoken by speakers from IC. The participants were more aware of varieties of English, especially those spoken by non-native speakers of English. However, English spoken by speakers from the EC was perceived as the most intelligible.
\end{abstract}

\section{Keywords}

varieties of English - accents - intelligibility - pronunciation 
บทคัดย่อ

ความหลากหลายของสำเนียงภาษาอังกฤษ: การศึกษาระดับความชอบและความเข้าใจ ของนักศึกษาสาขาภาษาอังกฤษ ชั้นปีที่ 2 มหาวิทยาลัยแม่โจ้

ประเทศไทยจัดอยู่ในกลุ่มประเทศที่ใช้ภาษาอังกฤษเป็นภาษาต่างประเทศ (Expanding circle EC) อีกทั้งประเทศไทยเป็นสมาชิกของประชาคมอาเซียน ดังนั้นผู้เรียนชาวไทยจึงควรตระหนักถึง ความหลากหลายของสำเนียงภาษาอังกฤษ งานวิจัยนี้ศึกษาทัศนคติ ความชอบและความสามารถใน การเข้าใจความหลากหลายของสำเนียงภาษาอังกฤษผ่านกิจกรรมเสริมการฟังของผู้ใช้ภาษาอังกฤษ ที่เป็นเจ้าของภาษา ที่ใช้ภาษาอังกฤษเป็นภาษาหลัก (Inner circle $-\mathrm{IC}$ ) ผู้ใช้ภาษาอังกฤษเป็น ภาษาที่สอง (Outer circle - OC) และกลุ่มผู้ใช้ภาษาอังกฤษเป็นภาษาต่างประเทศ (Expanding circle $-\mathrm{EC}$ ) นักศึกษาประเมินระดับความชอบต่อสำเนียงภาษาอังกฤษและความเข้าใจตัวบทพูด รวมถึงให้สัมภาษณ์แบบกึ่งทางการเพื่อได้ข้อมูลเชิงลึก ผลการวิจัยพบว่าผู้เรียนสาขาภาษาอังกฤษ ชอบภาษาอังกฤษแบบเจ้าของภาษาที่ใช้ภาษาอังกฤษเป็นภาษาหลักมากที่สุด $(\mathrm{IC})$ อีกทั้งผู้เรียน สาขาภาษาอังกฤษเริ่มตระหนักถึงสำเนียงภาษาอังกฤษแบบต่างๆ ที่พูดโดยผู้ที่ไม่ใช่เจ้าของภาษา มากขึ้น อย่างไรก็ตาม ผู้เรียนมีความสามารถในการเข้าใจภาษาอังกฤษจากกลุ่มผู้ใช้ภาษาอังกฤษ เป็นภาษาต่างประเทศ $(\mathrm{EC})$ มากที่สุด

\section{1 \\ Introduction}

According to Crystal (2003), what makes English a global language has little to do with the number of people who speak it. It is much more to do with who those speakers are because English is the first language of around just 25 percent of the world's English speakers and speakers who engage in English during lingua franca (ELF) interactions are non-native speakers of English.

English has become a working language in the ASEAN community, another instance of English as a lingua franca (ELF). Based on Jenkins (2004), the term "English as a lingua franca" refers to the situation in which English is used as a contact language among speakers who come from different first language and cultural backgrounds. According to Jenkins (2012) it can be said that English has served as the means of communication among speakers of different languages for many centuries. Firth (1996) states that ELF interaction can include native speakers of English but, in most cases, it is a contact language between people who share neither a common native tongue nor a common national culture and for whom English is an additional language. Jenkins (2006) stresses the need for English language learners to be ready for communication with the speakers of those diverse varieties of English.

With the advent of the ASEAN community, Thai students must recognize other varieties of English pronunciation, especially other varieties of English spoken by non-native speakers. However, it seems that Thai people are most 
frequently exposed to native-speaker models and especially General American English (GA) models, as can be seen in American pop culture such as songs, series and movies. According to Martin (2009), British films, television programs and pop music also have an impact on certain people, especially younger audiences who are likely to prefer either British or American English to their own accents. It is therefore our intention to explore students' perceptions of the varieties of English pronunciation. We expect that through learning activities focusing on listening to different varieties of English students will develop an awareness of the varieties of English and that such activities will enable different varieties of English pronunciation to have their place in the classroom.

\subsection{English in the ASEAN Community}

Kirkpatrick (2011) points out that English is used as a lingua franca in the ASEAN community. He proposes possible implications for English language teaching in the ASEAN context, where many different languages are used, calling it "multilingual model." In the ASEAN context, native-like competence and pronunciation is no longer the ultimate goal. There is no need for a multilingual person who is using English in a lingua franca context to sound like a native-speaker.

\subsection{Intelligibility}

Kenworthy (1987) sees intelligibility as being understood by a listener at a given time in a given situation. In this regard, the process of intelligibility implies that the more words a listener is able to identify accurately when said by a particular speaker, the more intelligible that speaker is. Kachru and Smith (2008) describe the ability to understand language as consisting of three elements: intelligibility, comprehensibility and interpretability. They define intelligibility as the ability to recognize a word or another sentence-level element of an utterance. Comprehensibility refers to the ability to recognize the meaning of words expressed and the intention expressed by the speaker in the proper context. It can be measured by having an utterance paraphrased or by asking questions about its contents. Interpretability involves cultural competency and the ability to understand the discourse strategies people use. In the current study, we focused on intelligibility.

\subsection{Varieties of English}

According to Galloway and Rose (2014), the unprecedented internationalization of the English language and the increasing role of English as a Lingua Franca (ELF) have resulted in a drastic change in the sociolinguistic landscape of English. English is used in communication across borders. This brings in 
varieties of English as they are widely used among speakers who share a different first language. Jenkins (2000) states that, essentially, these involve the transfer of features of the particular first language on to the pronunciation of English.

It is important to raise awareness among Thai students of the varieties of English pronunciation as they live in a world where English crosses national boundaries and, in the context of the ASEAN community, English brings people together from different language backgrounds and cultures. It is necessary to recognize the role and functions of the varieties of English. Native speaker norms may not be applicable to the world today. With reference to the "ownership" of English, Kachru (1992) has pointed out that English should be treated as a denationalized language in the sense that it belongs internationally. Widdowson (1994) also states that English no longer belongs to native speakers of English but to anyone who uses it.

\subsection{Varieties of English Pronunciation as Perceived by Non-Native Speakers of English}

Many studies about learner attitudes towards varieties of English carried out in non-native English-speaking countries have shown that the participants favor the English language used by native speakers of English (IC).

Kanoksilapatham (2013) surveyed 387 Thai university students' attitudes and aspirations with regards to their pronunciation models. It was found that the students held more favorable attitudes towards the model of native speakers, which differed from the expectations of teachers and academics. It is suggested in her study that teachers strike a balance between promoting a high standard of English in the classroom and exposing learners to other varieties of English.

Pilus (2013) surveyed 34 ESL students with respect to British, American and Malaysian English accents and found that the students seemed to show a preference for British English. However, the students rated the Malaysian English accent highly for pleasantness followed by the British and American accents. Malaysian English was also rated the highest for familiarity compared to both British and American accents. The high recognition rate for the Malaysian English accent in terms of pleasantness and familiarity is an indication that ESL students are comfortable identifying with their own native accents.

In addition, Pollard (2010) attempted to identify which varieties of English are considered to be suitable and explored the notion of perceived intelligibility through the eyes of 10 Korean learners of English. Although his study was inconclusive due to the relatively small sample size, the participants seemed to prefer General American English perceiving it as the most intelligible. Korean 
English was reported as intelligible in terms of familiarity because the Korean learners of English received large degrees of exposure.

A more recent study about the notion of English pronunciation norms, conducted by Jindapitak and Teo (2013), shed light on non-native varieties of English when the participants' perceptions were consistent with the notion of English as a lingua franca. They seemed to see non-native varieties as intelligible Englishes and considered them to be important where classroom learning was involved. They called for World Englishes to have their place in the language classroom by raising the awareness of the existence of varieties of English as this is believed to promote effective communication between non-native speakers. The exposure to Englishes in the pronunciation classroom is necessary and this can be done by including non-native speakers' stimuli as listening materials to improve students' understanding and awareness of non-native varieties of English. The study by Jindapitak and Teo (2012) also suggested that non-native English accents were perceived and stigmatized as non-standard or bad because the students lacked tolerance for linguistic differences.

To raise awareness of Global Englishes, Galloway and Rose (2014) conducted a study with third-year and fourth-year EFL students at a Japanese university. The participants were given a list of listening resources and required to listen to the provided ELF interactions and write a reflective journal about what they had heard. The results of the study showed that the students were interested in listening to and communicating with speakers from different cultural-linguistic backgrounds. They showed a preference for American English, although they were also interested in the EC and OC. Furthermore, it was found that the listening journals could be a useful tool in exposing students to Englishes and allowing them to perceive the importance of mutual intelligibility.

\subsection{Implementing the Pronunciation of Varieties of English in the Classroom}

Saengboon (2012) suggested familiarizing students with new varieties of English by providing them with more examples of non-native speakers using English. Sung (2015) offered some advice for introducing Global English (GE) to students within the classroom in order to raise their awareness of GE. Firstly, selecting listening materials that are motivating must be taken into consideration. Secondly, using "scripted" ELF conversations, which are recorded by speakers from different L1 backgrounds alongside "authentic" materials, should be considered. Finally, it is important to introduce students to the sociolinguistic backgrounds of English use around the world and present some facts concerning the varieties of English and ELF communication. 
Sung (2015) implemented bringing varieties of English into the language classroom by using listening tasks spoken by non-native English speakers. Sung interviewed students in his course, Varieties of English, in relation to non-native English accents. He found that students seemed to appreciate different varieties of English and ELF communication and developed a deeper understanding of the sociolinguistic reality of English today. They also showed more willingness and confidence in speaking English with a local accent but most students still held negative views about non-native varieties of English and their perceptions regarding the ideal instructional model did not change.

To examine the use of listening journals to raise awareness of the diversity of English, Galloway and Rose (2014) compiled Internet-based resources for their students to direct their own learning. They also made digital audio and video recordings of speakers from different Li backgrounds and countries as alternative resources to increase student exposure to the diversity of English. These ideas can be used by teachers who are planning to introduce varieties of English and to increase their students' exposure to the diversity of English.

The current study applied some suggestions from Sung (2015) and Galloway and Rose (2014) to select and prepare listening materials. Through listening materials concerning varieties of English offered to the English majors as supplementary listening, we have come up with the following research questions:

a.) What perceptions do English majors have towards varieties of English pronunciation, including native and non-native speakers of English?

b.) To what degree do English majors comprehend and prefer the speech of native and non-native speakers of English?

c.) Is there a correlation between the intelligibility of and preference for varieties of English?

The participants were 79 second-year English majors, enrolled in a course called "Sound and English Sound System". The participants were all Thai. They were aspiring users of English, studying in the Faculty of Liberal Arts, Maejo University, which is a public university located in Chiang Mai, Thailand, where English is used as a foreign language. 
To obtain quantitative data, a questionnaire was devised by adapting the existing survey developed by Pollard (2010). The participants listened to the selected speech samples once. They were then asked to rate their opinion of each speech from the best accent (5) to the worst accent (1) and to evaluate each speaker separately from the easiest to understand (5) to the hardest to understand (1).

The listening materials (video clips) were carefully selected. In data collection, the video clips samples selected for the current study varied only in the accents of speakers from EC, OC and IC because they represent varieties of English within these three concentric circles of Englishes. They were compiled from online resources. Each listening task included 3 different varieties of English as displayed by speakers from the expanding circle (EC), the outer circle (OC) and the inner circle (IC). Each video clip lasted 1-2 minutes. The video clips were unscripted to allow more exposure to real language use. Some were inspiring speech clips obtained from TED. The video clips were monologues and a conversation on a popular talk show to motivate the participants. The listening task was completed in a classroom two times a week. Altogether, there were 30 listening samples with different varieties of English presented to the participants within a period of 5 weeks. Appendix A shows the listening tasks completed in each class.

To obtain qualitative data, the participants' written responses to the video clip samples were encouraged and a semi-structured interview was conducted to obtain responses describing more in-depth views of the participants regarding their awareness of varieties of English pronunciation and their experience of listening activities.

To obtain more accurate information, the participants were informed that they could write reflective notes relating to accent perception and perceived intelligibility while listening to each audio sample. All speech samples were played only once because, as Pollard (2010) argues, further exposure to any given sample may increase its perceived intelligibility level. The interviews were carried out in Thai at the end of the course to allow the participants to expand their ideas and opinions and to discover supportive evidence for quantitative data.

The Likert scale data, analyzed by descriptive statistics, provided a summary of the data. Descriptive statistics were used to analyze the quantitative data for mean and standard deviation. The Correlation Coefficient was used to indicate the correlation between intelligibility and accent preferences. To analyze the qualitative data from the participants' written responses and interviews, we used the content analysis method. 


\section{$3 \quad$ Findings}

\subsection{Findings from the Questionnaires}

The results revealed that the English variety that was perceived to be the most favorable accent by the participants was English spoken by speakers from the IC, including American English, British English and Canadian English. However, English spoken by speakers from the EC was perceived as the most intelligible.

By having the participants rate their acceptance of each speech from the best accent to the worst accent, IC Englishes were perceived as most preferable $(M=3.32)$, followed by the varieties of English spoken by speakers from the EC $(\mathrm{M}=2.98)$ and the OC $(\mathrm{M}=2.74)$ as shown in Table 1. While listening to each speaker, the participants evaluated their understanding from the hardest to the easiest to understand; the results show EC Englishes were perceived as the most intelligible $(\mathrm{M}=2.84)$, followed by IC $(\mathrm{M}=2.74)$ and OC $(\mathrm{M}=2.71)$, respectively, as shown in Table 1.

The interpretation of the mean scores used for summarizing Likert scale data are as follows: $4.21-5.00$ was interpreted as excellent, 3.41-4.20 as good, $2.61-3.40$ as moderate, $1.81-2.60$ as poor, and $1.00-1.80$ as very poor. The data from Table 1 thus shows that the participants in this study favored and comprehended different Englishes spoken by speakers from the IC, OC and EC to a moderate degree.

To investigate the correlation between the intelligibility of and preference for varieties of English, the Spearman Rank Correlation Coefficient was used to determine the statistical significance of the coefficient of the two variables. Table 2 shows that the intelligibility and the preference significantly correlated $(\mathrm{r}=0.656)$, indicating a moderate correlation between the two variables. This indicates that the more intelligible the varieties of English were perceived to be, the more likely it was that the participants preferred the speakers' English.

TABLE 1 Participants' Perception of Preferences and Intelligibility

\begin{tabular}{llccl}
\hline & Perceptions & Mean & Std. Deviation & Meaning \\
\hline IC & Preference & 3.32 & 1.30 & moderate \\
& Intelligibility & 2.74 & 1.18 & moderate \\
OC & Preference & 2.74 & 1.17 & moderate \\
& Intelligibility & 2.71 & 1.16 & moderate \\
EC & Preference & 2.98 & 1.30 & moderate \\
& Intelligibility & 2.84 & 1.31 & moderate \\
\hline
\end{tabular}


TABLE 2 Correlation between Intelligibility and Preference of Varieties of English within the IC, OC and EC

English majors' perception (within IC, OC, EC)

\section{Intelligibility}

\begin{tabular}{ccc} 
& r & Sig. \\
\hline Preference & 0.656 & $0.000^{*}$
\end{tabular}

${ }^{*} \mathrm{p}<0.01$

\subsection{Findings from the Reflective Notes and the Interviews}

The responses to the reflective notes and interviews were used to answer the research question regarding the participants' perception towards the varieties of English spoken by native and non-native speakers of English from the inner circle (IC), the outer (OC), and the expanding circle (EC).

Firstly, the data obtained from the participants' reflective notes revealed that the participants tended to favor English spoken by speakers within the IC, which is regarded as the prominent model in the Thai education system. The majority of them perceived that native speakers' pronunciation was easy to understand and tended to believe that it was a clear English accent that sounds familiar to them. The following statements by some participants show how they responded to English spoken by speakers within the IC:

The accent is clear and it is a good accent to me.

The speaker has a very good accent and it is easy for me to understand what he said.

I like the accent; it is easy to understand.

Perfect. Though I can understand a bit, I like this accent.

It is pleasant to hear and sounds like a melody.

Apart from showing a preference for native English accents, many of the participants did not find it difficult to understand some varieties of English from the EC. Some of them reported that:

Indonesian English is similar to ThaiEnglish and I find it easy to understand. The accent is acceptable and it is good that I can understand it.

I like this accent and I can understand it.

She speaks quite well and her talk is easy for me to understand.

English with Thai accent is very clear for me and I can understand the talk very well. 
The above statements indicate that the participants' familiarity with varieties of English influenced their perception toward the varieties of English. However, listening to unfamiliar Englishes as spoken by non-native speakers within the OC and EC was perceived as difficult to understand and they were considered to be bad accents. Many of the participants expressed negative attitudes toward certain varieties of English. The following statements present some participants' responses:

I don't understand her.

It's hard to catch the meaning from such pronunciation. It sounds like an Indian accent which I found difficult to get. It is ok for me to understand, but the accent is bad. I don't like this accent, and I couldn't understand much of what he said. He doesn't speak clearly enough. It is hard to understand him. The accent sounds strange for me and is a hard one to understand.

It is clearly seen that negative views towards non-native speakers' accents had something to do with mutual intelligibility, which may be due to the fact that some Thai students were not familiar with Englishes within the OC and some within the EC.

In addition, some expressed their inability to understand Englishes by referring to speech rate. Many of them mentioned how the rate of speech influenced their intelligibility. Many perceived that some speech samples of different varieties were very difficult to understand because the speakers of the varieties spoke very fast. Some examples of the statements implying some frustration reflected by many of the participants are:

He speaks like a rapper. I don't understand him at all and I dislike this accent.

I don't understand much of it because he speaks too fast.

She speaks very fast and I can't catch the meaning at all.

He talks fast and it's hard to understand.

As the speech samples used in the research were unscripted and replayed at normal speed, these therefore accounted for students' negative feedback towards some varieties of English.

Secondly, in order to elicit the students' attitudes and perceptions as well as the intelligibility of varieties of English in detail, all the participants enrolled in the course were invited to an interview. However, only 26 participants out 
of 79 volunteered to participate in the interviews. The interviews were carried out individually in Thai. The interview data can be representative as some of the data corresponds to the findings gained from descriptive statistics. Also, it provides a potentially interesting and complementary perspective to the findings.

From the interview, the participants seemed to develop and increase an awareness concerning varieties of English that it is not necessary to acquire native-like competence. As one student commented, "Given a situation when we are in the airport where many passengers speak different languages, English is chosen as the lingua franca. And of course, passengers speak English in different varieties. As long as verbal communication is conducted regardless of what accents or a variety of English is perceived as comprehensible, communication is successful."

Besides, most of the participants appreciated the listening tasks given by non-native speakers of English in the video clips and encouraged the teacher to bring in more video clips spoken by non-native speakers of English to improve their listening skills. Incorporating video clips helped the participants to realize that English is not only spoken by native speakers of English and they felt that they should have more exposure to varieties of English in order to communicate successfully in their real life. The participants also expressed more confidence in using their Thai accents because they felt that their accents were not that bad compared to other varieties of English. One student admitted, "First, I was shy to speak English. I was afraid my accent was funny to the person I was talking to but the video clips spoken by non-native speakers boosted my confidence to speak English."

However, when asked about the goal of learning English pronunciation, most participants wished to achieve a "native-like" English accent, which refers to the English spoken in countries such as Britain and the United States. They wished to speak English like native speakers of English. They perceived that having native-like pronunciation such as American and Received Pronunciation was seen as prestigious and showed they had received a good education. For example, one student said, "to me, having native-like pronunciation can show that I am well-educated."

Most of the participants reported they were more familiar with the listening tasks given by native speakers of English such as American or British. Especially with American accents, many students said that they tended to better understand a speech given by Americans because they have more exposure to American pop culture such as series, movies and songs. Exposure to American pop culture positively affected the level of intelligibility of the listening tasks. 
Most of the participants said that they could comprehend the key message of a speech offered by Americans. However, when asked about the speech of speakers from countries of the outer circle such as Bangladesh, India and the Philippines, many of them said they did not understand the overall spoken dialogue. As one student said, "I can understand better when a Thai and Japanese speak English with their own local accents". Another student reported, "I don't really understand English with an Indian accent. Indians and Filipinos speak English too fast and their accents are not familiar to me. I feel I can understand English with Thai, Japanese, British and American accents better." It seems possible that the self-reported data lack of intelligibility was influenced by negative attitudes towards Indian and Filipinos; however, we found no indication of a prejudice in our interview data.

\section{$4 \quad$ Discussion and Pedagogical Implications}

\subsection{Pronunciation Preferences}

The findings from the study correspond to Pollard (2010); Kanoksilapatham (2013); Pilus (2013); and Galloway and Rose (2014) in that the participants prefer native norms. In other words, it was revealed that many participants preferred the inner circle Englishes. The participants held more favorable attitudes toward the model of native speakers of English. Many participants declared having native-like pronunciation as the goal of learning English pronunciation. Based on Smith and Nelson (2006), exposure to a certain accent for some considerable time facilitates intelligibility. According to the interview, only a few students seemed to develop and increase awareness concerning varieties of English. This may be explained by the fact that familiarity with certain varieties of English and perceptions of intelligibility and unintelligibility of certain varieties influenced the participants' degrees of preferences. For some participants who perceived some varieties of English as poor or bad English, this seems to be a common response for many Thai students who have been given English instruction in which a standard of native English norms has been emphasized. Either British or American English is regarded as a good and correct English accent that can label them as a successful language user. In addition, some responses reflecting the participants' prejudiced reactions or judgments about accented English indicate the influence of their belief that has been molded throughout their years of English learning in a traditional classroom where native English is standard. More importantly, the students' lack of awareness of linguistic diversity can be blamed for the stigma about nonnative accents (Jindapitak and Teo 2012). 


\subsection{Awareness of Intelligibility Rather Than Flawless Pronunciation}

From the findings, it seems that some participants appreciated the listening tasks given by non-native speakers of English since they reported that this can boost their confidence in speaking English. Bringing non-native listening resources into the English classroom can encourage the participants to believe that their Thai-accented English is not that bad and encourage them to speak out. It is important for teachers to educate their students in using English effectively to ensure mutual intelligibility, thus encouraging non-native speaking teachers to be in class or to provide extra activities with the help of today's technology, such as the Internet, to create opportunities for student exposure to the global English community. At the same time, it shows them that attaining the native-like goal should not be a major English learning goal (Jindapitak and Teo 2012). It is clear that there should be some changes concerning pedagogical practices to pave the way towards competent use of English by English language learners in today's world.

\subsection{The Impact of American and British Pop Culture}

Our study showed that the participants reported they are more familiar with the listening tasks given by native-speakers of English or IC. This may be because many Thai teenagers are exposed to American and British pop culture, the IC models of spoken English such as Hollywood films, American and British boy bands and series. It is no wonder that many Thai students perceive listening tasks offered by native speakers as more intelligible and reported that they are more familiar with the IC models of English or the listening tasks given by native speakers of English.

From this point, as long as Thai teenagers are exposed to American and British pop culture, it can be hard for varieties of English to have their place in the English language classroom to shape their attitudes and improve the intelligibility of other Englishes. Martin (2009) explains that British and American films, television programs, and pop music all affect certain audiences' preference and it appeared that younger audiences seem to express a clear preference for either American or British English.

As the majority of young Thai people have been exposed to popular media, in which American and British English are major sources of varieties of English, we assumed that the popular media can be one factor influencing English language learners' perceptions of varieties of English. This is also supported by Edwards (2016), who examined the factors impacting the use of American English pronunciation features including flapping, rhoticity and the lack of a low back vowel distinction among English major students at a University in Hong Kong. The degree to which the students used American English markers was 
related to their preference for American English, which was influenced by the American media.

\subsection{The Mismatch between What the Students Expect and the Academics Expect}

The fact that students in many studies e.g. Pollard (2010); Kanoksilapatham (2013); Pilus (2013); Galloway and Rose (2014) as well as the current study held more favorable attitudes toward native speaker models of English pronunciation poses a mismatch with the expectations of teachers and academics. Based on Kirkpatrick (2011), native-like competence and pronunciation is no longer the ultimate goal in the ASEAN context and there is no need for a multilingual person who is using English in lingua franca contexts to sound like a native speaker of English. Perhaps, it may take time and effort by English teachers to shape their students' attitudes toward other varieties of English and encourage them to appreciate other varieties of English. At least, the bright future for other Englishes in the English classroom that can be seen in this study is that most of the students seemed to appreciate the listening tasks given by nonnative speakers of English. As Saengboon (2012) suggested, to familiarize students with new varieties of English, more examples of non-native speakers using English should be incorporated in the classroom. In addition, to develop awareness of linguistic diversity, Jindapitak and Teo (2012) suggested having an in-class discussion which includes topics concerning accent differences to be brought up for the students to help them realize that all forms of English are equal. The current study has confirmed a change to a new model of communicative language classroom where students are expected to develop the realization that non-native English accents are on an equal footing with native English accents.

\section{5}

\section{Limitations of the Study and Suggestions for Further Research}

In data collection, the video clips samples selected for the current study varied only in the accents of speakers from EC, OC and IC. Future research should look into the investigation of other variables such as the stylistics variation, the regional variation and the idiosyncratic variation that could affect perception on the degree of liking and intelligibility. A breakdown of the participants' responses to various language varieties is also recommended for future research. In addition, more research on the issues of familiarity is recommended as it is one of the factors that may influence the attitudes and perceptions toward an accent and intelligibility. 
This study examined the perception and intelligibility of varieties of English by English major students in a university in Thailand through listening journals of speakers from IC, OC and EC. The results revealed that English spoken by speakers from the EC was perceived as the most intelligible. This is consistent with the studies by Pollard (2010) and Jindapitak and Teo (2013) which reported that the participants see non-native varieties as intelligible Englishes. However, the English variety that was perceived to be the most favorable accent by the participants was English spoken by speakers from the inner circle (IC), including American English, British English and Canadian English, which corresponds to Pollard (2010); Kanoksilapatham (2013); Pilus (2013); Nazari (2014); Galloway and Rose (2014). Moreover, the participants in this study held more favorable attitudes towards the native norms. Bringing the listening journals by speakers from IC, OC and EC shows that the participants are aware of the fact that English is used in communication across borders. To raise awareness of and to familiarize students of English with more varieties of English, it is recommended that there should be a place for varieties of English, from the OC and the EC, in the English language classroom. English language teachers should prepare more listening materials from speakers from OC and EC as alternative teaching and learning resources to encourage more exposure of Englishes.

The impact of globalization has changed trends in the English language classroom. The traditional concept of being native speakers with English norms has shifted to English used globally by non-native English speakers. Though this is a small-scale research, its findings indicate that it is important for English teachers to introduce their students to varieties of English in order to make them become aware of linguistic differences in the way English is used by non-native English speakers and help them develop a degree of mutual intelligibility as well as have them realize the broader roles and functions of English in today's society as a medium of global communication in multilingual contexts.

\section{References}

Crystal, David. 2003. English as a Global Language. Cambridge: Cambridge University Press.

Edwards, Jette G. Hansen. 2016. "Accents Preferences and the Use of American English Features in Hong Kong: A preliminary study". Asian Englishes 18, no. 3 (October): 197-215. https://doi.org/10.1080/13488678.2016.1225482. 
Firth, Alan. 1996. "The Discursive Accomplishment of Normality: On 'Lingua Franca' English and Conversation Analysis." Journal of Pragmatics 26, no. 2 (August): 237-259. https://doi.org/10.1016/0378-2166(96)00014-8.

Galloway, Nicola, and Heath Rose. 2014. "Using Listening Journals to Raise Awareness of Global Englishes in ELT.” ELT Journal 68, no. 4 (May): 386-396. https://doi.org/ 10.1093/elt/ccuo21.

Jenkins, Jennifer. 200o. The Phonology of English as an International Language. Hong Kong: Oxford University Press.

Jenkins, Jennifer. 2004. “The АВC of ELT...'ELF.” IATEFL Issues (December): 9. http:// citeseerx.ist.psu.edu/viewdoc/download?doi=10.1.1.597.6053\&rep=rep1\&type=pdf.

Jenkins, Jennifer. 2006. "Current Perspectives on Teaching World Englishes and English as a Lingua Franca." TESOL Quarterly 40, no.1 (January): 157-181. https://doi.org/ $10.2307 / 40264515$.

Jenkins, Jennifer. 2012. "English as a Lingua Franca from the Classroom to the Classroom." ELT Journal 66, no. 4 (October): 486-494. https://doi.org/10.1093/elt/ccso40.

Jindapitak, Naratip, and Adisa Teo. 2012. "Thai Tertiary English Majors' Attitudes toward and Awareness of World Englishes." Journal of English Studies 7, no. 1 (June): 74-105.

Jindapitak, Naratip, and Adisa Teo. 2013. "The Accent Priority in a Thai University Context: A Common Sense Revisited." English Language Teaching 6, no. 9 (August): 193-204.

Kachru, Braj. 1992. "World Englishes: Approaches, Issues and Resources." Language Teaching 25, no. 1 (January): 1-14. https://doi.org/10.1017/s0261444800006583.

Kachru, Yamuna, and Larry Smith. 2008. Cultures, Contexts, and World Englishes. New York: Routledge.

Kanoksilapatham, Budsaba. 2013. "Thai University Students' Voices Heard: Aspired Pronunciation Model." Journal of English Studies 8, no.1 (June): 124-153.

Kenworthy, John. 1987. Teaching English Pronunciation. London: Longman.

Kirkpatrick, Andy. 2011. "English as an Asian Lingua Franca and the Multilingual Model of ELT.” Language Teaching 44, no. 2 (May): 212-224. https://doi.org/10.1017/so26 1444810000145 .

Martin, Elizabeth. 2009. "World Englishes in the Media." In The Handbook of World Englishes, edited by Braj Kachru, Yamuna Kachru, and Cecil Nelson, 583-599. Oxford: Wiley-Blackwell.

Nazari, Mohsen. 2014. "Intelligibility of Iranian Learners at High-School and University." Elixir Lang \& Testing 76 (November): 28302-28306.

Pilus, Zahariah. 2013. "Exploring Es L learners Attitudes toward English Accents." World Applied Sciences Journal (Special Issue of Studies in Language Teaching and Learning) 21, no. 20: 143-152. 
Pollard, Andee. 2010. "The Study of English Varieties as Perceived by the Korean Learner" In Proceedings of the 2nd International Conference of Language and Communication, Bangkok, August 5-6, 2010, 1-11. Bangkok: NIDA.

Saengboon, Sangmanee. 2012. "Going ever more Multidimentional: The Mantra of English Language Teaching in the 21st Century." Journal of English Studies 7, no. 1 (June): 62-73.

Smith, Larry, and Cecil Nelson. 20o6. "World Englishes and Issues of Intelligibility." In The Handbook of World Englishes, edited by Braj Kachru, Yamuna Kachru, and Cecil Nelson, 428-445. Oxford: Wiley-Blackwell.

Sung, Matthew. 2015. "Exposing Learners to Global Englishes in ELT: Some Suggestions." ELT Journal 69, no. 2 (April): 198-201. https://doi.org/10.1093/elt/ccuo64.

Widdowson, Henry. 1994. "The Ownership of English." TESOL Quarterly 28, no. 2 (Summer): 377-389. https://doi.org/10.2307/3587438. 


\section{APPENDIX A}

\section{Listening Tasks}

Clip 1 https://www.youtube.com/watch?v=1tdLRkNOAHc

List the vocabulary you hear in the clip

What is the main idea of the clip?

After you watch the video clips, please rate from $5^{-1}$ how far you like the accents and how intelligible the given speech is to you.

\begin{tabular}{|l|c|c|c|c|c|}
\hline Accents & Best & Good & Fair & Poor & Worst \\
\hline & 5 & 4 & 3 & 2 & 1 \\
\hline \multicolumn{1}{|l|}{ Intelligibility } & Very easy & Quite easy & Moderate & Hard & Very hard \\
\hline & 5 & 4 & 3 & 2 & 1 \\
\hline
\end{tabular}

Clip 2 https://www.youtube.com/watch?v=g_CSsL3it9Y

List the vocabulary you hear in the clip.

What is the main idea of the clip? 
After you watch the video clips, please rate from $5^{-1}$ how far you like the accents and how intelligible the given speech is to you.

\begin{tabular}{|l|c|c|c|c|c|}
\hline Accents & Best & Good & Fair & Poor & Worst \\
\hline & 5 & 4 & 3 & 2 & 1 \\
\hline
\end{tabular}

\begin{tabular}{|l|c|c|c|c|c|}
\hline Intelligibility & Very easy & Quite easy & Moderate & Hard & Very hard \\
\hline & 5 & 4 & 3 & 2 & 1 \\
\hline
\end{tabular}

Clip 3 https://www.youtube.com/watch?v=GSymJlOGf_Y

List the vocabulary you hear in the clip.

What is the main idea of the clip?

After you watch the video clips, please rate from $5^{-1}$ how far you like the accents and how intelligible the given speech is to you.

\begin{tabular}{|l|c|c|c|c|c|}
\hline Accents & Best & Good & Fair & Poor & Worst \\
\hline & 5 & 4 & 3 & 2 & 1 \\
\hline
\end{tabular}

\begin{tabular}{|l|c|c|l|c|c|}
\hline Intelligibility & Very easy & Quite easy & Moderate & Hard & Very hard \\
\hline & 5 & 4 & 3 & 2 & 1 \\
\hline
\end{tabular}

